\title{
The Effect of Trust on Business Resilience of Traders in Muara Kuin Floating Market in Banjarmasin City
}

\author{
Akhmad Priyanka Tegar Pangabdi ${ }^{1}$, Yulius Slamet ${ }^{2}$, and Mahendra Wijaya ${ }^{3}$ \\ \{tegarpangabdi@student.uns.ac.id ${ }^{1}$ \} \\ ${ }^{1,2,3}$ Universitas Sebelas Maret, Surakarta, Indonesia
}

\begin{abstract}
Trust is a part of social asset very important to investment in the form of social relation; the presence of trust gives facilitations in transaction, as the lubricant or the access to the achievement of objective. Resilience is a way of surviving from any disruption or threat due to some changes compelling us to adapt to the change. Banjarmasin has cultural uniqueness due to the city's geographical condition consisting of many flowing rivers, native people using the river as transportation, trading center and floating market emerged in many places. As the consequence of time development in which urban development focuses more on land and many buildings covered the small rivers, the river transportation vehicles such as boats are no longer used, and the development of land markets make the existence of floating markets reduced and only a few of them survive. This study using quantitative research with survey method and using simple regression analysis. From this study we found the result how trust affected the business resilience of traders significanly, which is how the remaining traders business in the floating market survive. The trust they build from people surrounding them decide what kind of support be obtained.
\end{abstract}

Keywords: Trust, Business Resilience, Floating Market

\section{INTRODUCTION}

This floating market is a traditional market representing the typicality of Banjarmasin city. Polanyi explains that market has its distinctive economic system, by which the market is controlled, governed, and directed directly [1]. In exchanging process, floating market occurs on the river; generally Banjar people's houses follow the river stream and the houses are constructed on the river. Floating market conducts transaction on the river using traditional boat called jukung by local people, while traditional boat equipped with engine as its driving power on its rear part is called klotok. The sellers conduct trading transaction by coming close to the customers standing along the small quay called batang and then calling the sellers carrying the commodity with them on the boat. The trading activity is conducted from 5.00 to 9.00 a.m. Having conducted trading transaction activity on the floating market, most of sellers will continue their selling activity by harrowing the river edge, because there are many people houses in almost entire river edge in Banjarmasin city. The local native people's houses are constructed on the river with the porch designed to face the land and the river. Every house 
has small batang. The sellers who still have some commodities remaining usually harrow the river to look for the customers who wait for them passing through to buy their commodity. Jano said that market becomes a place where the commodity's sellers and buyers meet at certain time in certain interval. Traditional market is a part of urban activity occupying certain location [2].

Putnam [3] explains how trust becomes a very valuable asset in community. If an employer trusts another, it will reduce daily business cost. Trust is very desirable in a relationship established in business cooperation, particularly between seller and buyer, seller and fellow sellers, superior and subordinate, and asset owner and manager. The presence of trust can reduce too complex and complicated economic activity, but it can also be the gate to access other advantages such as cooperation, mutual help, information flow, and etc. Masten [4] explains how resilience becomes a dynamic system (individual, family, organization, and etc) to adapt to the situation successfully and positively, as its capacity in dealing with the threat harming the function of system, the life sustainability, or development. Building trust enables others whose trust we build become opened and help use in dealing with difficulties collectively. Theron [5] explains that when there is a significant difficulty and well adjustment is made with such the condition, the process is called resilience. Trust are necessary to building relationship between people surround us, in whether it is family, friend, or co-worker. Trust in people relationship like a bridge, the lower level of trust toward neighborhood the lower sense of belonging and trust its self contribute in satisfaction in life [6]. Good relationship between people has chance to improve resilience bussiness between trader. Patel and Gleason [7] explain that individual factor can reduce or enchance resilience with interaction that has been build between one an another whether person or community.

The more developing Banjarmasin city and the more developed city economy make the people's life better. All advances are due to the advance of technology, information, knowledge, and etc. However, the advances occurring degrade some elements of community in which the old generations undertaking their life following their original culture traditionally compete more difficultly with those conducting economic activity using more advance technology and method, and more practically and efficiently. It can be seen clearly that the people of Banjarmasin city formerly relying on river for being transportation and trading channel begin to leave such vehicles as boat and klotok (engine-powered boat) for transportation, trading, and distribution purposes because river has been replaced with streets and bridges constructed. People begin to switch to motor vehicles, automobile, and truck as commodity transporting or distributing tools. This research sees how the sellers in floating market defend their business from modernization change threat, by finding out how trust affects the business resilience of sellers in Muara Kuin floating market in Banjarmasin. It is in line with Fukuyama [8] describing that if people trust each other, they will work ethically and consistently with the norm prevailing so that the cost spent for running the business will be lower and vice versa. In order to keep exist, the traders in Muara Kuin Banjarmasin City can keep improve social relationship by building trust to people surround them, In the process they will have connection to acces information regarding trading, efficiently to do transaction, and acces of any kind support that might be provide by the people they had relationship.

Many studies shows how resilience needed for certain situation in certain environment. McEwen, et al [9] explain how develop community capital are necessary for flood resilience in UK, Canbolat [10] explain how social capital influences diversification strategies in Turkish business group, and Galappaththi et al [11] explain how shrimp farmer social-ecological resilience in northwestern Sri Lanka. In previous study showing how social capital and resilience are needed in society with certain problem occurred in their environment. In this 
study we are trying to explain how trust, which is part of Social Capital affected resilience business of floating market traders in Muara Kuin Banjarmasin City so they can keep survive from development and improvement in many sectors that threated traditional business. Trust necessary to build between family, fellow traders, business partner to improve their social relation in order to unlock many kind of support wether it is fund, information, strenght, and moral support.

\section{METHOD}

This research took place in Banjarmasin City, South Borneo. The author would study the sellers in Floating Market, so that the location selected was Muara Kuin Floating Market because it was a Traditional Floating Market still surviving, feeling the direct effect of change occurring in Banjarmasin City, and experiencing the faded trading activity. This study was a quantitative research with survey method, in which the informants consisted of the sellers in Muara Kuin Floating Market, and using questionnaire as the instrument of collecting data from every individual and documenting the data collected in the research including photographs and field note. Validity and reliability tests were conducted on the questionnaire. These tests were conducted to ensure that the questionnaire used for digging the data from informants valid and credible. The informants were selected using census method, in which the author calculated the number of informants manually because there were no certain number of sellers in Muara Kuin Floating Market and all sellers came from many areas. All of populations were used as informants. The number of informants constituting the sellers in Floating Market was $\mathrm{N}=50$.

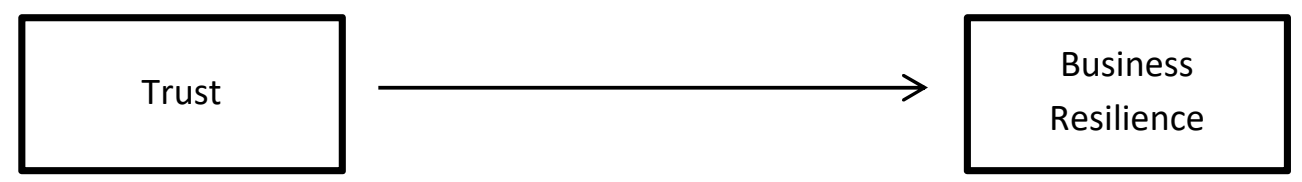

In his analysis, the author employed a simple regression analysis with trust being independent variable $(\mathrm{X})$ and Business Resilience being dependent variable (Y). From the result of simple regression analysis, the effect of trust as the independent variable $(\mathrm{X})$ on business resilience as the independent variable $\mathrm{Y}$ could be found out. The hypotheses proposed were: Ho: There is no significant effect of trust on business resilience of sellers in Floating Market and Ha: There is a significant effect of trust on business resilience of sellers in Floating Market. The author analyzed the data using simple regression analysis with SPSS program help to avoid the potential fault due to human error. Using this method, the size of effect of trust on business resilience of sellers in Muara Kuin Floating Market in Banjarmasin City could be found out.

\section{FINDING AND DISCUSSION}

Trust is a form of social relation relying on the relations established between an individual and another, thereby creating a strong bond to those establishing it. Marshall [12] explains how the trust can be viewed in 2 forms: generalized and personalized trust. Generalized trust is the one established in a beyond-personal environment, e.g. coworkers who have known each other. Personalized trust is the on growing among individuals with personal bond and the bond is a result of repeated interaction in a circle of people close to them. This finding indicates how the sellers in floating market build trust in their surrounding environment such 
as family, fellow sellers in floating market, and government. The sellers in Floating Market building trust in people surrounding become the new gate to access many things, dependent on the size of trust built in corresponding people. The data obtained from the questionnaire is presented below.

Table 1. The Trust of Traders and Family

\begin{tabular}{|c|c|c|}
\hline No & Question & Result \\
\hline 1 & Trust in Family & Trust very much: $64 \%$ Trust: $34 \%$ Occasional: $2 \%$ \\
\hline 2 & $\begin{array}{l}\text { Family supports the trading } \\
\text { activity }\end{array}$ & $\begin{array}{l}\text { Highly Supporting: } 46 \% \text { Supporting: } 50 \% \\
\text { Not Always: } 4 \%\end{array}$ \\
\hline 3 & Trust in running business & Very Often $38 \%$ Often: $58 \%$ Sometimes: $4 \%$ \\
\hline \multicolumn{3}{|c|}{ Table 2. The Trader's Trust in Fellow Traders } \\
\hline No & Question & Result \\
\hline 1 & Trust in another seller & Trust very much: $38 \%$ Trust: $56 \%$ occasionally: $6 \%$ \\
\hline 2 & $\begin{array}{l}\text { Conducting exchange with oth } \\
\text { sellers }\end{array}$ & Very Often: $42 \%$ Often 50\% Occasional: $8 \%$ \\
\hline 3 & Helping fellow sellers & Very often : $14 \%$ Often: $76 \%$ Occasional: $10 \%$ \\
\hline \multicolumn{3}{|c|}{ Table 3. The Trader's trust in Government } \\
\hline No & Question & Result \\
\hline 1 & Trust in government & Trust very much: $8 \%$ Trust: $88 \%$ Occasionally : $4 \%$ \\
\hline 2 & Government's New Program & Accepting directly : $80 \%$ Thinking of it first : $20 \%$ \\
\hline
\end{tabular}

From the data presented in tables 1-3, it can be seen the trust established by the sellers of floating market in family, fellow sellers, and government. Fukuyama [8] explains how trust becomes a social asset and it can be found from the smallest to the largest group, family and state. The result found indicates how the trust built between sellers and family gives many benefits including how the family supports the sellers, and the form of support can be fund, effort (energy), and moral. Portes [13] explains that the trust will give higher status of community and reasonable reward in the future; it can be seen from how people give debt collateral when they borrow some money. The trust built by the sellers ensures that the seller can run their business so that the family is getting surer that the business to be conducted will run smoothly. The result of research explains that the family with high trust in the sellers likely gives necessary helps. It indicates that if we are in trouble, we will have family who is willing to help as they are capable to do so. Fukuyama [14] suggests that trust becomes a foundation in social order in which reciprocal relation is not dependent on trust and it will arise spontaneously. In the trust built by the sellers of floating market in surrounding sellers give some benefits including helping each other if necessary, and facilitating each other's trading activity. This helps can be seen from the result of observation showing that the sellers using engine-powered boat seem to help the sellers using non engine-powered boat to tie their boat and deliver them to certain location; it occurs when the sellers have shared direction, or they trust each other. In relation to the sellers of floating market and the retailers supplying commodity, if the retailers have no money to pay the supply, the supplier will allow them to pay it later after the commodity has been sold out so that they will be avoided from price competition. Those with high trust share information with each other on the consumers' need because not all sellers have commodities needed by consumers and if it occurs they will 
inform other sellers having the commodities needed. The trust between sellers and government becomes an important part in the existence of floating market. This trust facilitates the government to understand the condition of Floating Market sellers and to determine the help necessarily given to them.

\section{Table 4. Persistence}

\begin{tabular}{|c|c|c|}
\hline No & Question & Result \\
\hline 1 & \multicolumn{2}{|c|}{$\begin{array}{c}\text { Asset when starting the business }>2 \text { millions: } 22 \% 1 \text { million- } 2 \text { millions: } 32 \% \\
500 \text { thousands }-1 \text { million: } 32 \% \\
<500 \text { thousands: } 14 \%\end{array}$} \\
\hline 2 & Weekly income & $\begin{array}{l}>750 \text { thousands: } 24 \% 500 \text { thousands- } 750 \\
\text { thousands: } 16 \% \\
200 \text { thousands }-500 \text { thousands: } 42 \% \\
<200 \text { thousands: } 8 \%\end{array}$ \\
\hline 3 & Decreased income & $\begin{array}{l}\text { Very often: } 2 \% \text { often: } 68 \% \\
\text { Occasional: } 30 \%\end{array}$ \\
\hline 4 & Increased income & $\begin{array}{l}\text { Very often : } 12 \% \text { often: } 80 \% \\
\text { Occasional: } 8 \%\end{array}$ \\
\hline \multicolumn{3}{|c|}{ Table 5. Adaptability } \\
\hline No & Question & Result \\
\hline 1 & $\begin{array}{l}\text { Commodity quantity today } \\
\text { compared with that in the } \\
\text { beginning of trading }\end{array}$ & $\begin{array}{l}\text { Increases: } 16 \% \text { Decreases: } 62 \% \\
\text { Equal: } 20 \% \text { reduced: } 2 \%\end{array}$ \\
\hline 2 & $\begin{array}{l}\text { Selling commodities different } \\
\text { from those usually sold }\end{array}$ & $\begin{array}{l}\text { Very often: } 4 \% \text { Often } 60 \% \text { Occasional: } 26 \% \\
\text { Never: } 10 \%\end{array}$ \\
\hline 3 & $\begin{array}{l}\text { Your commodity type when } \\
\text { starting to trade }\end{array}$ & $\begin{array}{l}>3 \text { types : } 40 \% 2-3 \text { types: } 34 \% \\
1-2 \text { types: } 20 \% 1 \text { type: } 6 \%\end{array}$ \\
\hline 4 & $\begin{array}{l}\text { Your commodity type when } \\
\text { starting to trade }\end{array}$ & $\begin{array}{l}>3 \text { types: } 40 \% 2-3 \text { types: } 42 \% \\
1-2 \text { types: } 14 \% 1 \text { type: } 4 \%\end{array}$ \\
\hline \multicolumn{3}{|c|}{ Table 6. Transformability } \\
\hline No & Question & Result \\
\hline 1 & $\begin{array}{l}\text { Trading in other markets than } \\
\text { Muara Kuin River floating } \\
\text { market }\end{array}$ & $\begin{array}{l}\text { Very often : } 8 \% \text { Often: } 44 \% \text { Occasional: } 24 \% \\
\text { Never } 14 \%\end{array}$ \\
\hline 2 & $\begin{array}{l}\text { Trading time when starting to } \\
\text { trade }\end{array}$ & $\begin{array}{l}\text { About } 4 \text { a.m.: } 24 \% \text { about } 5 \text { a.m.: } 44 \% \\
\text { About } 6 \text { a.m.: } 20 \% \text { after } 6 \text { a.m.: } 2 \%\end{array}$ \\
\hline 3 & Trading time today & $\begin{array}{l}\text { About } 4 \text { a.m.: } 24 \% \text { about } 5 \text { a.m.: } 42 \% \\
\text { About } 6 \text { a.m.: } 22 \% \text { about }: 2 \%\end{array}$ \\
\hline
\end{tabular}

Tables $4-6$ show the business resilience of sellers in Muara Kuin Floating Market in Banjarmasin City. This business resilience is divided into three: persistence, adaptability, and transformability. Walker and Folke [15] explains that there are three aspects of resilience: persistence, adaptability, and transformability. Persistence is an ability of being buffer in undertaking function and structure thereby can be preserved; adaptability is an ability of reorganizing and learning to deal with uncertainty and shock; transformability is an ability of dealing with changes in the system by means of creating new directions. Viewed from the 
business resilience, the Floating Market sellers show some changes: decreased and increased incomes in certain period, describing how the sellers deal with the effect of changes in order to keep existent as the floating market sellers. The data above also show how the sellers adapt to the changes occurring, as indicated with the types of commodities sold and the increased quantity of commodities adjusted with the consumers' need and how the transformation occurs in the sellers' trading time and trading place. Every traders have different business resilience which is depend how much impact that affected to their business, and how much trust that they build between people that surround them. Data explain that there is variety between every trader resilience business from their persistence, adaptability, and transformability.

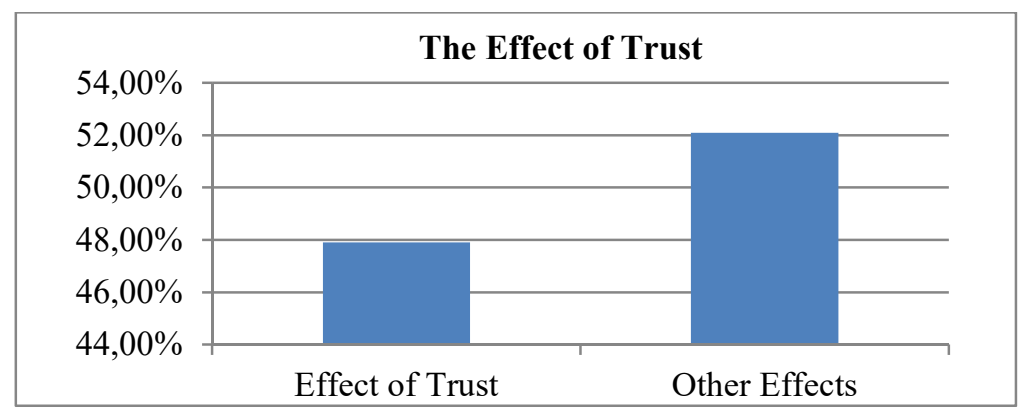

Figure 1. The Effect of Trust on Business Resilience

Figure 1 shows the result of regression analysis with output model summary indicating that the coefficient of determinacy ( $\mathrm{R}$ Square) value is 0.479 . Therefore, the coefficient of determinacy is 0.479 equal to $47.9 \%$. For that reason, it can be concluded that the trust affects the Business Resilience of Sellers in Muara Kuin Floating Market in Banjarmasin city by $47.9 \%$, while the rest of $52.10 \%$ is affected by other effects. Those effects include other social assets and other assets such as economic, cultural, and etc.

Table 4 shows the significant effect of trust as independent variable $(\mathrm{X})$ on business resilience as dependent variable (Y). The hypotheses proposed are as follows:

Ho: There is no significant effect of trust on the business resilience of floating market sellers.

Ha: There is a significant effect of trust on the business resilience of floating market sellers.

From the result of regression analysis, it can be seen the size of the effect of trust on business resilience. It shows significance level of 0.000 , meaning that trust as independent variable (X) affects Business Resilience as dependent variable at significance level of less than 0.05 , so that it can be said that there is a significant effect. Therefore, Ho is not supported and Ha is supported.

\section{CONCLUSION}

The result of research shows that there is a significant effect of trust on business resilience, from result of regression analysis showing at significance level of 0,000 . Therefore, it can be concluded that there is a significant effect of trust built by the traders in Muara Kuin Floating Market in Banjarmasin on their business resilience. In this study the result that we found are how trust effected resilience business of traders floating market, in this study resilience consist three part, that is persistence, adaptability, and transformability. Trust that had been build 
between traders and people surround them like family, fellow trader, and government effected how traders capability in persistence to stand againts development of the city that threat existence of floating market, with trust itself traders receive many form of support from certain individual that traders had social relationship. Trust its self-helping in adaptability of trader againts changes in society that had been made by advancing technology and knowledge, where's trust helping to unlock acces information from every individual that traders make social relationship. With information \& support traders receive from social relationship they made, its helping traders to make new ways of bussiness to survive againts changes in system. In order to gain strong resilience business, traders in floating market need to expand their social relationship or business partner with different kind of people and improve their trust gain many kind of support or information that necessary to improve traders business.

\section{REFERENCES}

[1] Damsar, Sosiologi Ekonomi. Jakarta: Raja Grafindo Persada, 1997.

[2] I. Aliyah, B. Setioko, and W. Pradoto, "Spatial flexibility in cultural mapping of traditional market area in Surakarta (A case study of Pasar Gede in Surakarta)," City, Cult. Soc., vol. 10, no. 36, pp. 41-51, 2017.

[3] R. D. Putnam, Bowling Alone. New York: Simon \& Schuster, 2000.

[4] A. D. van Breda and L. Dickens, "The contribution of resilience to one-year independent living outcomes of care-leavers in South Africa," Child. Youth Serv. Rev., vol. 83, no. November, pp. 264-273, 2017.

[5] L. C. Theron, "Toward a culturally and contextually sensitive understanding of resilience: Privileging the voices of black, South African young people," J. Adolesc. Res., vol. 31, no. 6, pp. 635-670, 2016.

[6] H. Hamdan, F. Yusof, and M. A. Marzukhi, "Social Capital and Quality of Life in Urban Neighborhoods High Density Housing,” Procedia - Soc. Behav. Sci., vol. 153, pp. 169179, 2014.

[7] R. B. Patel and K. M. Gleason, "The association between social cohesion and community resilience in two urban slums of Port au Prince, Haiti," Int. J. Disaster Risk Reduct., vol. 27, no. September 2017, pp. 161-167, 2018.

[8] F. Fukuyama, Trust: The Social Virtues And The Creation Of Prosperity. New York: Simon \& Schuster, 1995.

[9] L. McEwen, A. Holmes, N. Quinn, and P. Cobbing, “Learning for resilience': Developing community capital through flood action groups in urban flood risk settings with lower social capital," Int. J. Disaster Risk Reduct., vol. 27, no. October 2017, pp. 329-342, 2018.

[10] E. Ozkan-Canbolat, "Social capital influences on business groups' diversification strategies," Procedia - Soc. Behav. Sci., vol. 24, pp. 1436-1443, 2011.

[11] I. M. Galappaththi, E. K. Galappaththi, and S. S. Kodithuwakku, "Can start-up motives influence social-ecological resilience in community-based entrepreneurship setting? Case of coastal shrimp farmers in Sri Lanka," Mar. Policy, vol. 86, no. May, pp. 156$163,2017$.

[12] S. Yulius, Modal Sosial dan Kemiskinan. Surakarta: UNS Press, 2012.

[13] Damsar and Indriyani, Pengantar Sosiologi Ekonomi. Jakarta: Kencana Prenada, 2013.

[14] Field, Modal Sosial. Bantul: Kreasi Wacana, 2016.

[15] A. Ashkenazy, T. Calvão Chebach, K. Knickel, S. Peter, B. Horowitz, and R. Offenbach, "Operationalising resilience in farms and rural regions - Findings from fourteen case studies,” J. Rural Stud., vol. 59, pp. 211-221, 2018. 
